iRAPA

\title{
Essential Key to Success for Hospitality Academicians in India: The Requisite Focus on Morality and Veracity
}

\author{
Viveka Nand Sharma ${ }^{*}$, Arvind Hans ${ }^{b}$, Shailendra Kumar Raic \\ $a, b$ Usha Martin University, Ranchi-Jharkhand - India \\ CIIMT University, Meerut, Uttar Pradesh - India
}

\section{A R T I C L E I N F O}

\section{Article history:}

Received on: 19 January 2022

Revised on: 19 January 2022

Accepted on: 20 January 2022

Published on: 04 February 2022

\section{Keywords: \\ Hospitality \\ Morality \\ Teaching \\ Tourism \\ Value \\ Veracity}

\section{A B S T R A C T}

There is a critical role of teaching in advancing Hospitality and Tourism Education all over the world, and a lack of honest and integrated teachers, facilitators, and professors may lead to low-skilled workers, who in turn may become liabilities to society in later stage and slow the growth of the industry. Veracity and morality need to be inculcated in Children for being value-oriented people. People having high ethics and values become responsible citizens to serve the nation. It becomes the academicians' responsibility to inculcate morality, veracity, authenticity, social responsibility, and courage to stand up for what they believe in by leading by example. Academicians must design their delivery and evaluation system in such a way so that students adhere to all quality norms. Warren Buffet advised three qualities to be a successful employee: Veracity, intelligence, and energy, and he advocates that if the employee does not have veracity, he will kill the other two. Marilyn Price -Mitchell (2015) advocates that all academicians must practice the infusion of veracity in classroom culture, and all students must be inculcated with five fundamental values: responsibility, respect, fairness, trustworthiness, and morality from the entry-level school education system.

Copyright (C) 2021 iRAPA International Journal of Business Studies. Published by International Research and Publishing Academy - Pakistan. This is an open access article licensed under CC BY:

(https://creativecommons.org/licenses/by/4.0)

\section{Introduction}

Global education monitoring report 2020/21 on Accountability in education: meeting our commitments states, "Everyone believes that today's young children are the future of tomorrow, but hardly people think about the process of inculcating the quality required by a leader." A large percentage of current jobs is provided by tourism and hospitality, which will continue to grow as a result of the demand for these industries. Teachers are guiding principles committed to creating an environment where all community members pursue the highest possible academic performance level and inculcate morality and veracity values in their students. The mammoth and lucrative career options available in this Industry make it a sought-after course. Because of the demanding workplace and fierce competition, workers are forced to compromise on the product's quality for the client. Therefore, it becomes significant for the job entrants to be well aware of ethics and values. Academic veracity in the hospitality industry becomes crucial, enhancing the quality of customer services (McCabe \& Pavela, 2000; Vannucci \& State, 2017). Presently, they are minimal studies subjected to academic morality and Veracity in India's hospitality context. The concept of authenticity is an activity, an institution that is considered the closest to completeness and wholeness according to Nillson and Rodney (2005). The word Value has different synonyms and is used in different spheres of life. Imparting value education has become a necessity for the overall

\footnotetext{
Ranchi-Jharkhand - India

E-mail addresses: viveksharmabhm@gmail.com

DOI: https://doi.org/10.48112/iijbs.v2i1.125

Copyright (C) $2021 i$ RAPA International Journal of Business Studies

Published by International Research and Publishing Academy

This is an open access article licensed under CC BY

(https://creativecommons.org/licenses/by/4.0)
}

* Corresponding author: Viveka Nand Sharmaa, Usha Martin University,

\section{How to cite:}

Sharma, V. N. ., Hans, A. ., \& Rai, S. K. . (2021). Essential Key to Success for Hospitality Academicians in India: The Requisite Focus on Morality and Veracity. iRAPA International Journal of Business Studies, 2(1), 35-42. https://doi.org/10.48112/iijbs.v2i1.125 
development of the students. Teachers of all the segments breed academic immorality and plagiarism. Therefore, it becomes difficult to avoid plagiarism (Boehm, 2016).

Previous literature and various hospitality industry factors had been used to identify the learning environment's ethical and unethical parameters (Marneros et al., 2020). The role of faculty is judged in instilling ethical conduct among the students. Hotel Industry has been vocal about the lack of moral values in young graduates (Nillsen, 2004 b). Industry advocates that the students passing out of University/ Colleges are not prepared to accept the extended duty hours/overtime, break shifts, extra work, etc. Young graduates bluntly refuse to work extra and want to be compensated for long hours with extra salary/ compensatory offs. It has been felt that the Millennials and today's generation are more vocal about their rights than their past generation.

In India, Certificates, diplomas, undergraduate, postgraduate hotel management, and tourism courses are offered in abundance and designed to cater to the needs of users; that is why many private players, i.e. Lalit School of Hospitality, ITC HMI, Institute Of Hotel Management by Taj, OCLD and Jaypee Institute of Hotel Management are having a free reign over this sector due to their expertise in offering expertise and developing the required skill set in young students.

Due to the worldwide spread of COVID-19, the employment rate has been reduced in all sectors. The paper discusses how entrepreneurship skills can be developed to make students job-ready. Students will be ready to accept more challenging roles as entrepreneurs under various circumstances, and they will be utilizing the job market for developing opportunities in the hospitality and tourism sector. Skill gap study for Madhya Pradesh undertaken by National Skill Development Corporation, 2013 has reported youth aspiration mismatch between student aspirations and job opportunities in the state are two folds- soft skills and behavioral aspects and technical skills with prospective employees lacking in either or both of them.

The Government's New Education Policy discusses the significance of skill-based education for students. Introducing skills at the nascent stage will make them employable. The skills acquired during the secondary studies will equip the students with the desired skill set if they must work early due to natural calamities / tragic situations / mishaps in the family.

This research paper analyses the morality and veracity of tourism and hospitality academicians in contributing to the up-gradation of quality education and skillsets required by the students. Our study aims to fill the gaps identified by Iberahim et al. (2013) and map the hospitality academician perspective on student academic immorality. Hence, our research objective is to identify the gap between morality and veracity in teaching practices. The following section presents a literature review followed by a methodology section where we found several academic immorality practices. Next, the authors present findings and suggestions which emerged from the study. Finally, conclusions, recommendations are drawn for academicians to develop perspectives on academic immorality.
This research paper addresses how the education system can be value-oriented with its prominent role in the education system. The faculty members in the education system must not be pressured to give undue favours to the students. Students are the future leader of tomorrow. If they do not become strong in ethics, not moulded properly for the challenging environment, it will break them if they do not become strong individuals. emphasized that there should be autonomy in higher education to make the process beneficial for the students and all the stakeholders, i.e. students, parents, teachers, entrepreneurs, and everyone involved.

Several academicians emphasized that the business graduates are trained about making a profit and profitoriented business rather than transaction cost economics and financial education. (Miller, 2011) conceptualized that the disciplined environment cultivates students with good ethical behaviour characteristics. Various authors (Mustapha et al., 2017; Newman, 2008) supported the concept of teaching ethics and values to students for their future growth.

Various researchers, i.e. (McCabe \& Pavela, 2000; Milman, 2001; Niederkrotenthaler et al., 2012; Nillsen, 2004a; PARK, 2003; "Handb. Res. Synth.," 1994), claims that the business studies students turn out to be most unauthentic and without moral principles in their approach towards the education system. This thought process was validated by Diekhoff et al. (1996) and Mustapha et al. (2017). Most research studies have focused on cheating to judge the students' veracity and authenticity. The faculty and the students do not regard malpractices in the academics/teaching industry. There is no clarity to measure students' authenticity, and even if the student cheats, they are not rated as unethical.

Therefore, it is imperative to state what measures must be adopted by the students for their overall development. Various academicians (Ethics, 2011; Lambert, 2005) examined different levels of students. The previous research (Lee et al., 2019) suggests that students' profitcentered approach makes them unethical towards life learning. As per the Ministry of Human Resource Development (2015); The National Assessment and Accreditation Council (NAAC) of India believe in assessing higher education as an internationally proven methodology to judge the quality of Institutions.

\section{Material \& Methods}

The current study used a survey instrument to gather the required information with teaching practitioners and academicians in various Hotel Management institutions to determine the morality and veracity of teaching practices. The questionnaire was sent to 115 respondents, out of which 75 responses were received. Out of these, 12 were not included in the study due to incompleteness, and 63 were found fit for the study. The research was conducted from October 2020 to February 2021 through purposive sampling.

The instrument was divided into two themes. The first part comprised questions related to socio-demographic information. The second part was discussed to find teachers' perspectives on why students engage in academic immorality. The instrument was adapted from various literature works (Iberahim et al., 2013; Lambert, 2005; Park, 2003). 


\section{Results \& Discussion}

\section{Meaning of Veracity}

The faculty members were asked about veracity. As per the responses received from the Academicians, Veracity is closest to high value and ethics. Building students' future on solid ethics and values is essential, enabling the budding entrepreneurs and hoteliers to make the right decision and not compromise their products' quality. Responses also reveal that veracity is weighed equally with morality, moral principles, sincerity, wholeness, and completeness.

Morality and Veracity in Hospitality and Tourism Education is facing challenges

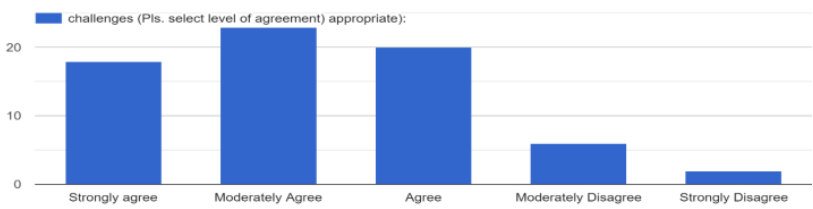

Fig. 1. Respondent's opinion regarding morality and veracity

Academicians were asked whether morality and veracity in hospitality and tourism education face challenges. $23 \%$ of faculty moderately agreed with the statement and $20 \%$ agreed with the statement, and $18 \%$ strongly agreed with the fact.

Current batch sizes of students in a course are the primary reason for facing challenges

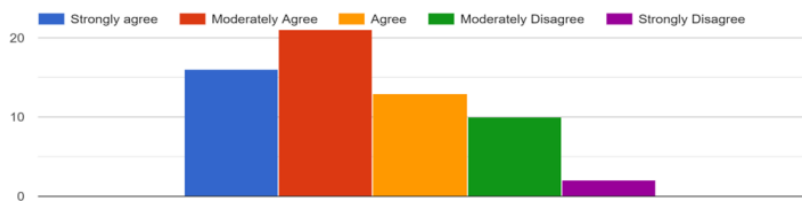

Fig. 2. Responses regarding the role of current batch side

The chart opines that students' batch size concerns imparting quality education to students. The batch size must be limited for a better understanding of students. If the batch size is small, the faculty become visible and audible. The small size of students is especially helpful in communicating and making the students understand the concepts.

The ideal group size for theory and practical classes in hospitality education
Table 1

Ideal group size of students for theory and practical sessions

\begin{tabular}{ccc}
\hline Ideal group size & Theory & Practical \\
\hline Less than 20 & 2 & 38 \\
$21-40$ & 30 & 21 \\
$41-60$ & 26 & 1 \\
$61-80$ & 2 & 0 \\
More than 81 & 1 & 1 \\
\hline
\end{tabular}

Respondents' opinions regarding the pressure mounted on students for getting good grades in the examination for securing good marks, and students follow cheating to prove their records. $42.9 \%$ of respondents find this a primary reason, and $33.3 \%$ find this secondary.

The practice of cheating is a dominating characteristic based on age group and gender

Table 2

Responses regarding cheating as dominating characteristics

\begin{tabular}{|c|c|c|c|c|c|}
\hline Age & Count & Percentage & Gender & Count & Percentage \\
\hline $15-20$ years & 45 & 71.4 & Male & 24 & 38.1 \\
\hline 21-25 years & 29 & 46 & Female & 6 & 9.5 \\
\hline \multirow[t]{2}{*}{ 26-30years } & 2 & 3.2 & $\begin{array}{l}\text { Prefer } \\
\text { not to } \\
\text { say }\end{array}$ & 37 & 58.7 \\
\hline & Total & 100 & & Total & 100 \\
\hline
\end{tabular}

The practice of cheating is dominating characteristics based on education

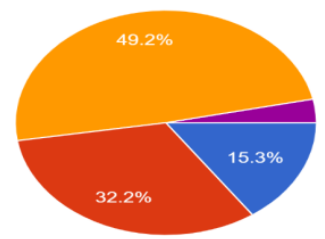

Class 10 th pass student Class 12 th pass students Graduate students Postgraduate students M.Phil./PhD Research scholars

Fig. 3. Responses regarding the practice of cheating as dominating characteristics based on education

Table 3

Responses regarding the preference of cheating as per students of various grades

\begin{tabular}{ccc} 
Parameters & Value & Percentage \\
\hline Class 10th pass students & 9 & 15.3 \\
Class 12th pass students & 19 & 32.2 \\
Graduate students & 29 & 49.2 \\
Postgraduate students & 0 & 0 \\
M.Phil./Ph.D. Research scholars & 2 & 3.4 \\
& Total & 100 \\
\hline
\end{tabular}

Ten significant causes of cheating and list its priority from 1-10 (1 most minor and ten most) 
Table 4

Causes of Cheating identified by Academic Staff

\begin{tabular}{|c|c|c|c|c|c|c|c|c|c|c|c|}
\hline Causes of cheating & 1 & 2 & 3 & 4 & 5 & 6 & 7 & 8 & 9 & 10 & Total \\
\hline a) Getting Good grades & 11 & 4 & 6 & 5 & 6 & 5 & 2 & 5 & 6 & 12 & 62 \\
\hline $\begin{array}{l}\text { b) Students feel that cheating is } \\
\text { a good thing/ or enjoy violation } \\
\text { of academic rules }\end{array}$ & 11 & 10 & 15 & 1 & 4 & 6 & 4 & 3 & 4 & 1 & 49 \\
\hline c) Want to influence others & 9 & 4 & 13 & 4 & 5 & 7 & 3 & 4 & 3 & 3 & 55 \\
\hline $\begin{array}{l}\text { d) Poor instructions and } \\
\text { confusing lectures }\end{array}$ & 11 & 8 & 4 & 7 & 7 & 2 & 8 & 4 & 4 & 2 & 57 \\
\hline e) Peer pressure & 13 & 8 & 5 & 6 & 9 & 4 & 3 & 5 & 1 & 4 & 58 \\
\hline $\begin{array}{l}\text { f) The student feels cheating is } \\
\text { his/ her right }\end{array}$ & 20 & 7 & 6 & 5 & 3 & 6 & 1 & 3 & 4 & 3 & 52 \\
\hline g) Ignorance by faculty & 12 & 4 & 7 & 5 & 7 & 7 & 5 & 4 & 5 & 1 & 57 \\
\hline $\begin{array}{l}\text { h) Involvement of student in } \\
\text { extracurricular activities }\end{array}$ & 15 & 4 & 5 & 5 & 7 & 4 & 3 & 6 & 4 & 3 & 56 \\
\hline $\begin{array}{l}\text { j) Lack of diligence among } \\
\text { instructors at catching cheaters }\end{array}$ & 11 & 3 & 12 & 2 & 9 & 2 & 5 & 5 & 4 & 3 & 56 \\
\hline
\end{tabular}

A total of ten indicators were developed and asked respondents why the student engages in dishonest practices? Most teachers believe that students deliberately indulge in dishonest practices for grabbing good grades and peer pressure. Few teachers believed that faculty ignorance and lack of diligence among instructors at the cheating center were also significant reasons. The findings are consistent with the studies of Iberahim et al. (2013); Kelly De Lambert (2005).

Percentage of students who admire or appreciate cheating

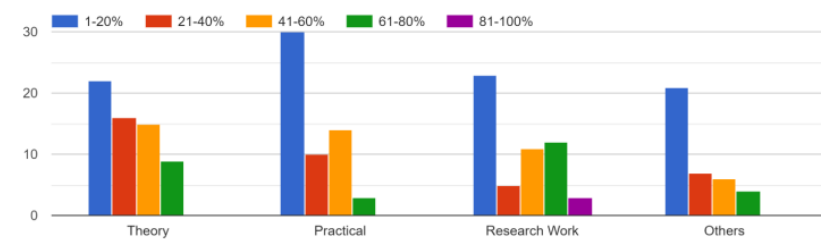

Fig. 4. Percentage of students who opt for cheating in theory, practical and research

The online method of teaching will help in bridging the gap between expectations of the hospitality industry and the quality of education provided by the Institutes
Table 5

Students involved in cheating during theory, practical, and research work

\begin{tabular}{cccccc}
\hline Percentage & $\mathbf{1 - 2 0} \%$ & $\mathbf{2 1 - 4 0} \%$ & $\mathbf{4 1 - 6 0 \%}$ & $\mathbf{6 1 - 8 0} \%$ & $\mathbf{8 1 - 1 0 0 \%}$ \\
\hline Theory & 22 & 16 & 15 & 9 & 0 \\
Practical & 30 & 10 & 14 & 3 & 0 \\
Research Work & 23 & 5 & 11 & 12 & 3 \\
Others & 21 & 7 & 6 & 4 & 0 \\
\hline
\end{tabular}

Table 6

Responses regarding the online mode of education in bridging the gap

\begin{tabular}{cc}
\hline Parameters & Count \\
\hline strongly disagree & 16 \\
disagree & 16 \\
neutral & 19 \\
agree & 8 \\
strongly agree & 4 \\
\hline
\end{tabular}


Table 7

Different parameters of judging the academic immorality

\begin{tabular}{|c|c|c|c|c|}
\hline Parameters & Yes & No & May be & Total \\
\hline The existing academic system can control academic immorality & 13 & 27 & 23 & 63 \\
\hline Repetition of questions in assignments/examinations leads to cheating & 21 & 27 & 15 & 63 \\
\hline A student feels guilty about the cheating performed by him/her & 40 & 18 & 05 & 63 \\
\hline $\begin{array}{c}\text { Is the pressure built on teachers by the Institute/ society/ peer pressure/ anti-social elements to } \\
\text { award marks for a student unable to perform? }\end{array}$ & 24 & 36 & 03 & 63 \\
\hline Is cheating an integral part of the examination system? & 12 & 36 & 15 & 63 \\
\hline As a faculty, I used cheating as a tool during our exams & 7 & 48 & 8 & 63 \\
\hline Morality and veracity in a student make them a better human being & 61 & 0 & 2 & 63 \\
\hline The existing curriculum is capable of developing entrepreneurship skills & 18 & 32 & 14 & 63 \\
\hline Faculty should be rewarded and socially recognized for reducing the cheating percentage & 51 & 0 & 12 & 63 \\
\hline Students are pressurized by their parents/ society to get good grades in the examination & 21 & 15 & 27 & 63 \\
\hline
\end{tabular}

The frequency of the situation

Table 8

Responses regarding the frequency of building the pressure for awarding the marks

\begin{tabular}{|c|c|c|c|c|c|c|c|}
\hline Parameters & Authorities & $\begin{array}{l}\text { Once in a } \\
\text { semester }\end{array}$ & $\begin{array}{l}\text { Twice in a } \\
\text { semester }\end{array}$ & $\begin{array}{l}\text { More than twice } \\
\text { in a semester }\end{array}$ & Regular practice & Never & No comments \\
\hline By institute & 6 & 9 & 3 & 1 & 1 & 9 & 9 \\
\hline By society & 3 & 3 & 2 & 2 & 1 & 3 & 5 \\
\hline By friends & 1 & 1 & 2 & 2 & 5 & 3 & 1 \\
\hline $\begin{array}{l}\text { By anti-social } \\
\text { elements }\end{array}$ & 1 & 1 & 2 & 1 & 2 & 5 & 5 \\
\hline
\end{tabular}

The best three methods of evaluation being adopted at surveyed hospitality educational institute for practical examinations

\section{Table 9}

Responses regarding the acceptance of evaluation methods at hospitality colleges for practical exams

\begin{tabular}{cc}
\hline Parameters & Select the best three methods \\
\hline a. Project report & 26 \\
b. PowerPoint presentations & 26 \\
c. group discussions on the topics & 17 \\
d. Field reports & 23 \\
e. Traditional descriptive methods of \\
writing recipes \\
f. Hands-on (Evaluation of skills) \\
g. Seminar Presentations \\
h. Viva by external experts
\end{tabular}

The best three methods of evaluation being adopted at surveyed hospitality educational institute for theory examinations.
Table 10

Acceptance of evaluation methods at hospitality colleges for theory exams

\begin{tabular}{cc} 
Parameters & Select best three \\
\hline a. Project report & 15 \\
b. PowerPoint presentations & 15 \\
c. group discussions on the topics & 11 \\
d. Subjective assignments & 34 \\
e. Traditional descriptive methods of question & 25 \\
papers & f. MCQs \\
g. Seminar Presentations & 37 \\
\&subjective questions. & 9 \\
\hline
\end{tabular}

Table 11

Responses regarding different ways to reduce cheating

\begin{tabular}{lcc}
\hline \multicolumn{1}{c}{ Parameters } & Count & Percentage \\
\hline $\begin{array}{c}\text { a) Academic discipline } \\
\text { b) Transparency in evaluating } \\
\text { system }\end{array}$ & 44 & 70 \\
c) Recognition of the students & 22 & 47.6 \\
d) Changes in the evaluation & 28 & 35 \\
$\quad \begin{array}{c}\text { system } \\
\text { e) More weightage on practical } \\
\text { research }\end{array}$ & 29 & 44 \\
f) Involvement of parents in \\
$\quad \begin{array}{c}\text { evaluating } \\
\text { g) Regular audit of academic } \\
\text { and evaluation }\end{array}$
\end{tabular}


Students who have high ethics and values are more competent in the Industry

Table 12

Responses regarding high ethics and values amongst students

\begin{tabular}{ccc}
\hline Parameters & Frequency & Percentage \\
\hline Strongly disagree & 7 & 12 \\
Disagree & 2 & 2 \\
Neutral & 18 & 38 \\
Agree & 11 & 18 \\
Strongly agree & 23 & 30 \\
\hline
\end{tabular}

The qualities required to develop entrepreneurship skills in students

\section{Table 13}

Responses regarding the requirement of entrepreneurship skills in students

\begin{tabular}{|c|c|c|}
\hline Parameters & Count & Percentage \\
\hline a) Entrepreneurship skills subject & 32 & 51 \\
\hline b) Offering hands-on training & 41 & 65.1 \\
\hline c) Let the students run various & 33 & 52.4 \\
\hline $\begin{array}{l}\text { d) Making the congenial } \\
\text { atmosphere for }\end{array}$ & 18 & 28.6 \\
\hline $\begin{array}{l}\text { e) Promotion of incubation } \\
\text { ideas/Promotion }\end{array}$ & 23 & 36.5 \\
\hline $\begin{array}{l}\text { f) Getting innovative projects } \\
\text { funded }\end{array}$ & 18 & 28.6 \\
\hline $\begin{array}{l}\text { g) Let the student invest his funds } \\
\text { for }\end{array}$ & 10 & 16 \\
\hline $\begin{array}{l}\text { h) Less emphasis on theory and } \\
\text { more focus }\end{array}$ & 13 & 21 \\
\hline
\end{tabular}

Is there a need to revise all the course curriculum in the Hospitality and Tourism industry's current scenario?

Table 14

Requirement of revision of course curriculum in the hospitality \& tourism sector

\begin{tabular}{ccc}
\hline Parameters & Count & Percentage \\
\hline Strongly disagree & 4 & 6.35 \\
Disagree & 0 & 0 \\
Neutral & 8 & 12.7 \\
Agree & 19 & 30.16 \\
Strongly agree & 32 & 50.79 \\
Total & $\mathbf{6 3}$ & $\mathbf{1 0 0}$ \\
\hline
\end{tabular}

\section{Observations}

The researcher used the tool of an open-ended questionnaire to gain an insight into morality and veracity from the respondents. Following observations were concluded based on the responses.

1. Veracity is closer to the soundness of moral principles.

2. Morality and Veracity in Hospitality and Tourism Education is facing significant challenges

3. Most respondents moderately agreed that the current batch sizes of students in a course are primary reasons for facing challenges of imparting education

4. Thus, according to the survey above, the apt group size for practical should be less than 25 students, and for theory sessions, the group size should be between 35-40 students.

5. Most respondents agreed that students are pressured by their parents / society to get good grades in the examination, which is the primary reason for cheating.

6. The practice of cheating is a dominating characteristic in the age group of 15-20 Years.

7. The practice of cheating is dominating characteristic most in students of Diploma and Graduate courses.

8. Most respondents agreed that faculty should be rewarded and socially recognized to reduce or bring down a cheating percentage.

9. Significant causes of cheating are:

a. Getting Good grades

b. Students feel that cheating is a good thing/ or enjoy violation of academic rules

c. Want to influence others

$10.60 \%$ of respondents stated that most students admire or appreciate cheating in theory exams.

11.It is still debatable that the online teaching method will help bridge the gap between expectations of the hospitality industry and the quality of education provided by the Institutes.

12. Respondents opined that the existing academic system could control academic immorality if the following aspects are practices

a. Avoiding repetition of questions in the examination from last year's question papers.

b. A student feels guilty about the cheating performed.

c. No pressure should be built on academicians by authorities of the Institute/ Society/ Peer/ Antisocial elements to award marks for a student unable to perform.

d. Authorities of the Institute maintain an academic discipline.

e. Regular academic audits are performed to maintain transparency in the evaluation.

13. Most respondents agreed that Morality and Veracity in a student make them better human beings and develop entrepreneurship skills in students.

14. Most respondents agreed that students with high ethics and values are more competent.

15. Most respondents agreed that there is a need to revise the course curriculum of all the courses.

16. Most respondents laid stress on the implementation of a new education policy for all IHMs

\section{Conclusion}

The purpose of this study was to examine students academic immorality from a teacher's perspective from the existing gap in knowledge (Iberahim et al., 2013). The study supports the view of Lambert (2005) and Park (2003) regarding teachers' diligence, and the garb to achieve good grades are the primary reasons for students' immorality in the academic sector. Education is an ecosystem; teachers are the primary components of this system. An ecosystem cannot run smoothly without its other significant stakeholders like Institutional authorities, parents, philanthropic organizations, and Government. The research study judges the ethics and values of educators in doing their work diligently. It has been observed that a conducive ethical environment plays a significant role in nurturing the budding hoteliers and future aspirants of the hospitality industry(McCabe \& Pavela, 2000) 
In the last couple of years, values, veracity, and transparency are rapidly going down in the education system due to interference by education mafias, poor academic inputs by academicians, peer pressure, and parents' pressure on their children to achieve maximum marks or highest grades. It is also observed that the current quality of the evaluation system has gaps that lead to cheating and degrade quality education and challenge our purpose in maintaining morality and veracity in our teaching practices.

The research study results offer future directions for further study to researchers. The research survey was conducted in IHM's and a few universities, so its results might not be generalized to other institutions and universities. Therefore, future research could increase the sample of universities, and the comparative study can analyse the constructs contributing to academic immorality in the teaching sector.

\section{References}

Boehm, D. (2016). Fundamental Values: Morality and Academic Veracity On College Campuses Today. Retrieved from http://hdl.handle.net/: http://hdl.handle.net/2027/spo.5240451.0001.014

Diekhoff, G. M., LaBeff, E. E., Clark, R. E., Williams, L. E., Francis, B., \& Haines, V. J. (1996). College cheating: Ten years later. Research in Higher Education, $37(4)$ 487-502. https://doi.org/10.1007/BF01730111

Ethics, E. \&. (2011). Excellence \& Ethics for Schools. http:/ / www2.cortland.edu/dotAsset/317302.pdf

Iberahim, H., Hussein, N., Samat, N., Noordin, F., \& Daud, N. (2013). Academic Dismorality : Why Business Students Participate in these Practices? Procedia - Social and Behavioral Sciences, 90(October), 152-156. https://doi.org/10.1016/j.sbspro.2013.07.076

Kelly De Lambert, N. E. A. L. T. (2005). Academic Dismorality Among Students In Tertiary Institutions: A Literature Review. Waikato Journal of Education, 11(2), 83-99.

Lee, M. J., Kang, H., Choi, H., Lee, J., \& Olds, D. (2019). Students' perceptions of hospitality education quality in the United States higher education: Domestic versus international students. Journal of Hospitality, Leisure, Sport \& Tourism Education, 25, 100212. https://doi.org/10.1016/J.JHLSTE.2019.100212

Marneros, S., Papageorgiou, G., \& Efstathiades, A. (2020). Identifying critical success competencies for the hospitality industry: the perspectives of professionals. Journal of Teaching in Travel and Tourism, 20(4), 237-261. https://doi.org/10.1080/15313220.2020.1745732

McCabe, D., \& Pavela, G. (2000). Some Good News About Academic Veracity. Change: The Magazine of Higher Learning, 32(5), 32-38. https://doi.org/10.1080/00091380009605738

Miller, D. (2011). Objective Knowledge (Foreword to a translation). Ezagutza Objektiboa. Ikusmolde Bat.

Milman, A. (2001). Hospitality and Tourism Curriculum Development. Journal of Teaching in Travel \& Tourism, $1(4)$, 65-76. https://doi.org/10.1300/j172v01n04_05

Mustapha, R., Asilah, N., \& Ali, N. (2017). An Empirical Survey of Academic Dismorality At a Major Public Universities in Recent Years : the Malaysian Evidence. Multidisciplinary Journal, 5(3), 43-49.
Newman, J. (2008). The Idea of a University (F. M. Turner (ed.)). Yale University Press. https://doi.org/doi:10.12987/9780300153460

Niederkrotenthaler, T., Fu, K., Yip, P. S. F., Fong, D. Y. T., Stack, S., Cheng, Q., \& Pirkis, J. (2012). Changes in suicide rates following media reports on celebrity suicide: a meta-analysis. Journal of Epidemiology and Community Health, 66(11), 1037-1042. https://doi.org/10.1136/jech-2011-200707

Nillsen, R. (2004a). Can the Love of Learning be Taught? Journal of University Teaching \& Learning Practice, $1(1)$, $1-9$. http://ro.uow.edu.au/jutlphttp://ro.uow.edu.au/jutl $\mathrm{p} / \mathrm{vol} 1 /$ iss $1 / 2$

Nillsen, R. (2004b). The Concept of Veracity in Teaching and Learning. Symposium on Promoting Academic Veracity, 2(November 2004), 1-9.

PARK, C. (2003). In Other (People's) Words: Plagiarism by university students--literature and lessons. Assessment \& Evaluation in Higher Education, 28(5), 471-488. https://doi.org/10.1080/02602930301677

The handbook of research synthesis. (1994). In H. Cooper $\&$ L. V Hedges (Eds.), The handbook of research synthesis. Russell Sage Foundation.

Vannucci, C., \& State, M. (2017). Academic Veracity in Hospitality Programs. 21(2), 1-9. 